\title{
経皮的腎尿管結石摘出術の腎機能への影響について
}

一DMSA 腎シンチグラフィーによる長期経過観察—

\author{
東北大学医学部泌尿器科学教室（主任折笠精一教授） \\ 千 葉 裕 折笠 精一
}

\section{A CLINICAL STUDY OF THE INFLUENCE OF PERCUTANEOUS NEPHROURETEROLITHOTOMY ON RENAL FUNCTION USING ${ }^{99 \mathrm{~m}}$ Tc-DMSA RENAL SCINTIGRAPHY}

Yutaka Chiba and Seiichi Orikasa

Department of Urology, Tohoku University School of Medicine, Sendai, Japan

(Director: Prof. S. Orikasa)

To clarify the influence of percutaneous nephroureterolithotomy (PNL) on renal function, ${ }^{99 \mathrm{~m}} \mathrm{Tc}$ DMSA renal scintigraphy was performed preoperatively and 3,6 and 12 months after the procedure.

In 50 stone-containing renal units, 48 patients, changes of DMSA renal uptake rate were investigated for determination of individual renal function. In 3 cases with staghorn calculi which complicated with pyelonephritis during PNL procedure, DMSA renal uptake rate was decreased after PNL. On the other hand, DMSA renal uptake rate was almost stationary after PNL in other cases.

In 21 renal units (42\%), the postoperative renal scintigrams showed low uptake or cold areas at nephrostomy tracts.

These results indicate that control of infection during PNL is important to maintain renal function.

\footnotetext{
要旨：1983年 6 月より1986年 9 月までに，当科で PNLを施行した症例のうち，PNL 後 1 年間の経過観 察が可能であった48症例50腎に対して ${ }^{99 m} \mathrm{Tc}-\mathrm{DMSA}$ 腎シンチグラフィーを行い，DMSA 腎摂取率の変 化より, PNL 後の分腎機能の長期経過について検討を行った。

DMSA 腎摂取率により，PNL 後 1 年間の分腎機能の変化を観察すると，50腎中 38 腎 (76\%)が経過良 好群，18腎 (18\%) が中間群， 3 腎（6\%）が経過不良群であった。

経過不良群 3 腎は，すべて術後発熱を合併したサンゴ状腎結石であった。術後発熱を合併したサンゴ 状腎結石13腎の PNL 後の平均 DMSA 腎摄取率は, 術後発熱を合併しなかったサンゴ状腎結石12腎の平 均 DMSA 腎摂取率に比較して，有意に低下していた。

また，50腎中21腎で，PNL 後の腎シンチグラム上，腎瘻掩入部に一致した low density or cold area の残存を認めた.

感染を合併しやすいサンゴ状腎結石においても, PNLを更に腎機能への影響の少ない方法として確立 していくためには，十分な化学療法などにより，感染を予防することが重要と考えられた。
}

\section{緒 雼}

泌尿器科領域における超音波穿刺技術の進歩と内視 鏡の発達は, 腎孟尿管内の内視鏡的手術を可能とした。 そのなかでも現在最も広く普及しているのが，経皮的 腎尿管結石摘出術 (Percutaneous Nephroureterolithotomy，以下 PNL と略す) である。

本法は, 1976年 Fernström and Johansson ${ }^{1}$ により
初めて報告されたが，1981年 Alken ら 2 の超音波砕石 器を用いた報告以後, 機器の発達ともあいまって PNL の報告は急激に増加した ${ }^{3) \sim 5)}$ ．私達の教室でも1981年 12月に初めての PNLに成功して以来，1988年 3 月ま でに施行した症例数は700例に達した ${ }^{677)}$. しかし本法 は腎実質を穿通して腎孟腎杯内へ内視鏡を㨀入するた め，当初により腎機能への影響が懸念されてきた。そ 
こで私達は, 優れた分腎機能検査法として注目されて いる ${ }^{99 \mathrm{~m}} \mathrm{Tc}$-Dimercaptosuccinic acid (DMSA) 腎シン チグラフィー8)用いて DMSA 腎摂取率より, PNL 後 1 年間という長期にわたって, 分腎機能の变化を観 察検討をおこなったので報告する。

\section{対象および方法}

\section{[対象]}

対象は1983年 6 月より1986年 9 月までに当科で PNLを施行した症例のうち，特に大きな合併症もな く, 残石も米粒大以下の, いわゆる臨床的成功例の中 から, PNL 後 1 年間の長期経過観察が可能であった 48 症例50腎である。性別は男23症例 24 腎, 女 25 症例 26 腎 で，それぞれ両側症例を 1 例ずつ含む。年齢は 2 歳か ら74歳で， 2 歳と 6 歳の小児および74歳と70歳の高齢 者を除くと19歳から66歳である. 患側は左側23腎, 右 側27腎であり, 主要な結石の存在部位は, サンゴ状腎 結石23症例25腎(両側 2 症例), 腎孟腎杯結石18症例18 腎, 尿管結石 7 症例 7 腎である。

\section{[方法]}

\section{1. 当科に招ける PNLの方法}

当科に拉ける PNLの方法" を簡単に述べると以下 の如くである。すなわち，硬膜外麻酔下腹臥位にて， 起音波（観測装置 ALOKA SSD-650または SSD-720， 探触子 ASU-32 3.5MHz) 監視下に, 後腋窩線上第 12 肋骨下または第 $10 〜 11$ 肋間より， $22 \mathrm{G}$ 穿刺針を結石の 破砕・摘出に最適と思われる腎杯に刺入し，そのルー トを0.018“ランダキスト・ガイドワイヤー，19G 金属 ダイレーター, $5 \mathrm{Fr}$ ポリェチレン・ダイレーター, 0.038”J-チップ・ガイドワイヤーの順序で拡張した後, $6 \sim 8 \mathrm{Fr}$. 筋膜 ダイレーター, 9 24Fr. 金属ダイレー ターにて拡張し腎瘻を造設した。このルートより内視
鏡を插入し, 強力超音波, 電気水圧衝撃波, レーザー 等を使用して，結石を破砕摘出することになる.

2. PNL 後の DMSA 腎摂取率の変化とイメージ像 の観察

48症例50腎で PNL 前, および PNL 後 3 力月, 6 力 月，12カ月に ${ }^{99 m} \mathrm{Tc}-\mathrm{DMSA}$ 腎シンチグラフィーを行 い, DMSA 腎摂取率を測定した。 DMSA 腎摂取率の測 定は川村らの方法 ${ }^{10)} に$ 従い, ${ }^{99 \mathrm{~m}} \mathrm{Tc}$-DMSA を成人では $5 \mathrm{mCi}$ ，小児では $2 \mathrm{mCi}$ 静注し，約 2 時間後に腎シンチ グラムの撮影と摂取率の測定を行った. DMSA 腎摂取 率は，投与量に対する腎相当部のカウントの比率を， バックグラウンドと腎の深さ，および時間的減衰より 補正計算し求めた。 また，静的イメージ像の正面像及 び側面像を観察し，腎瘻插入部に一致した low uptake area あるいは cold area の残存の有無についても検 討を行った。

なお，有意差検定は，Student の $\mathrm{t}$ 分布検定，および $\chi^{2}$ 検定によった。

\section{結 果}

1. 結石部位と PNL の成績（表 1)

各結石部位別の, 術前平均 DMSA 腎摂取率は, サン ゴ状腎結石で最も低く $17.5 \pm 4.5 \%$, 腎孟腎杯結石で最 も高く,ややばらつきが大きいが $19.9 \pm 8.0 \%$ ，尿管結 石では $18.0 \pm 5.7 \%$ でった。 また平均腎㾞留置期間, 平均 PNL 施行回数は, サンゴ状腎結石で最も長くか つ多く，それぞれ48.1日および4.6回，腎㙉腎杯結石で 最も短くかつ少なく，それぞれ16.2日および1.7回で あった。術後発熱合併は50腎中15腎（30\%）の処置に 際して見られ，15腎中13腎がサンゴ状腎結石であった。 また，体外衝撃波結石破砕術（以下 ESWL）を併用し た症例は，サンゴ状腎結石 8 腎であった。

表 1 結石部位と術前平均腎摂取率および PNLの成績

\begin{tabular}{|c|c|c|c|}
\hline & $\begin{array}{c}\text { サンゴ状堅結石 } \\
25 \text { 腎 }\end{array}$ & $\begin{array}{c}\text { 腎孟腎杯結石 } \\
18 \text { 腎 }\end{array}$ & $\begin{array}{c}\text { 尿管續石 } \\
\text { 管 }\end{array}$ \\
\hline $\begin{array}{c}\text { 術前平均腎攝取率 } \\
(\text { mean } \pm \text { SD) }\end{array}$ & $17.5 \pm 4.9 \%$ & $19.9 \pm 8.0 \%$ & $18.0 \pm 5.7 \%$ \\
\hline $\begin{array}{l}\text { 平均堅瘻 } \\
\text { 留置期間 }\end{array}$ & $\begin{array}{c}48.1 \text { 日 } \\
(10-110 \text { 日 })\end{array}$ & $\begin{array}{c}16.2 \text { 日 } \\
(7-49 \text { 日) }\end{array}$ & $\left(\begin{array}{c}26.1 \text { 日 } \\
(7-53 \text { 日 })\end{array}\right.$ \\
\hline $\begin{array}{l}\text { 平均 PNL } \\
\text { 施行回数 }\end{array}$ & $\begin{array}{c}4.6 \text { 回 } \\
(1-12 \text { 回 })\end{array}$ & $\begin{array}{c}1.7 \text { 回 } \\
(1-4 \text { 回 })\end{array}$ & $(1-6$ 回 $)$ \\
\hline $\begin{array}{l}\text { 発熱合併 } \\
\text { 症例* }\end{array}$ & $\begin{array}{c}13 \text { 腎 } \\
(52.0 \%)\end{array}$ & $\begin{array}{c}1 \text { 蜸 } \\
(5.6 \%)\end{array}$ & $\begin{array}{c}1 \text { 婜 } \\
(14.3 \%)\end{array}$ \\
\hline $\begin{array}{c}\text { ESWL併用 } \\
\text { 症例 }\end{array}$ & $\begin{array}{c}8 \text { 堅 } \\
(32.0 \%)\end{array}$ & 0 & 0 \\
\hline
\end{tabular}


2. Control studyとしての正常腎に括けるDMSA 腎摂取率実測值の変動抽よび平均腎摂取率の測定結果 (表 2)

正常対照群として，25歳から32歳までの腎機能正常 の男子ボランティア 4 名を用いた. ${ }^{99 \mathrm{~m}} \mathrm{Tc}$-DMSA 腎シ ンチグラフィーを，1週間から 2 カ月の間隔で，ほぼ 同じ条件で各々 3 回ずつ施行し, DMSA 腎摂取率を測 定した。 4 名の右腎, 左腎および両腎の, 平均 DMSA
腎摂取率は, 右腎 $24.6 \pm 1.5 \%$, 左腎 $23.2 \pm 1.8 \%$, 両 腎47.8土2.4\%であった。これらの值は, 川村の報告 ${ }^{10)}$

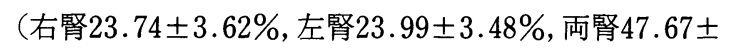
4.91\%）とほぼ同程度の値を示した。

また各症例に拀いて，3回の DMSA 腎摄取率実測 值の変動幅は, DMSA 腎摂取率の平均值を 100 とした 場合, 最少 5.3 から最大 12.3 とった。このような DMSA 腎摂取率の変動や測定誤差に関しての詳細な

表 2 正常腎に括ける DMSA 腎摂取率実測值の変動および平均腎摂取率の測定結果

\begin{tabular}{|c|c|c|c|c|c|c|}
\hline \multirow{2}{*}{ 症 例 } & \multirow{2}{*}{ 左右 } & \multicolumn{3}{|c|}{ DMSA 腎摂取率実測値 } & \multirow{2}{*}{ 平均値 } & \multirow{2}{*}{$\begin{array}{l}\text { 平均値を100 } \\
\text { 之場合の } \\
\text { 変動幅 }\end{array}$} \\
\hline & & 1 回目 & 2 回目 & 3 回目 & & \\
\hline \multirow{3}{*}{$\underset{32 \mathrm{y}}{\mathrm{C}} \mathrm{Y}}$. & 左 & $20.5 \%$ & $21.6 \%$ & $19.9 \%$ & $20.7 \%$ & 8.2 \\
\hline & 右 & 22.6 & 24.1 & 24.2 & 23.6 & 6.8 \\
\hline & 両 & 43.1 & 45.7 & 44.1 & 44.3 & 5.9 \\
\hline \multirow{3}{*}{$\underset{31 \mathrm{y}}{\mathrm{R}} \mathrm{K}}$. & 左 & 22.9 & 22.5 & 24.1 & 23.2 & 5.9 \\
\hline & 右 & 25.2 & 26.6 & 28.4 & 26.7 & 12.0 \\
\hline & 両 & 48.1 & 49.1 & 52.5 & 49.9 & 8.8 \\
\hline \multirow{3}{*}{$\underset{28 \mathrm{y}}{\mathrm{S}}$ I } & 左 & 23.5 & 22.8 & 24.8 & 23.8 & 8.4 \\
\hline & 右 & 24.6 & 24.0 & 25.3 & 24.6 & 5.3 \\
\hline & 両 & 48.1 & 46.8 & 50.1 & 48.4 & 6.8 \\
\hline \multirow{3}{*}{$\underset{25 y}{\mathrm{~K}} \mathrm{O}$. } & 左 & 24.0 & 26.0 & 24.9 & 24.9 & 8.0 \\
\hline & 右 & 21.8 & 24.7 & 24.2 & 23.5 & 12.3 \\
\hline & 両 & 45.8 & 50.7 & 49.1 & 48.4 & 10.1 \\
\hline
\end{tabular}

図 1 サンゴ状腎結石 (非発熱群) 12 腎に括ける PNL 後の DMSA 腎摂取率の変動

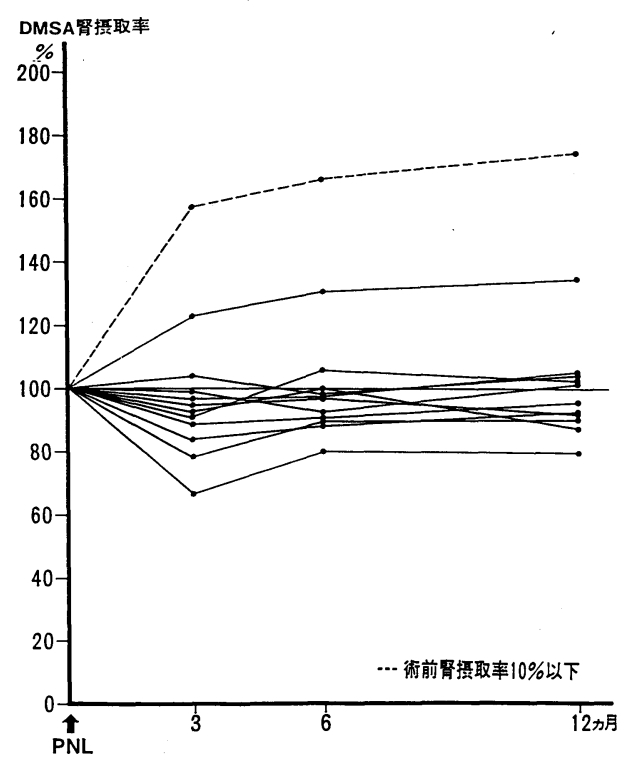

因 2 サンゴ状腎結石 (発熱群) 13腎における PNL 後 の DMSA 腎攝取率の変動

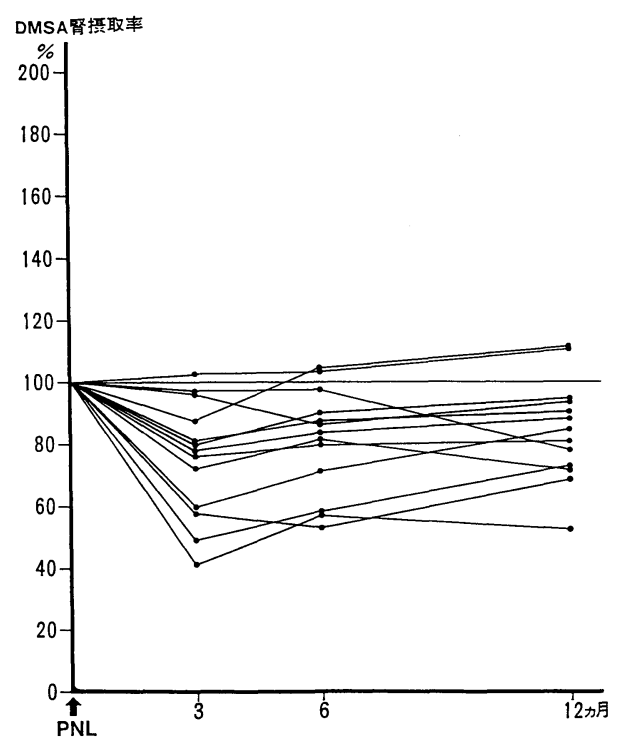


報告は他になく, 以下に述べる PNL 後の DMSA 腎取 率の変化についての検討に扔いては, 私達のデータを もとに，術前の腎湶取率の括よそ15\%以上の変動を有 意と見なす事とした。

3. 結石部位別 DMSA 腎摂取率の長期経過観察結 果

サンゴ状腎結石のらち, 術後発熱を合併しなかった 12腎の PNL 後の腎摂取率の変化をみると， 1 腎で 3 カ月後に術前の値の $66.7 \%, 6$ 力月後に $79.9 \%$ へと幾 分低下しているが, 他の11腎は良好な経過であった(図 $1)$.

それに対して，術後発熱を合併したサンゴ状腎結石 13腎では，明らかに術後腎摂取率の低下寸る症例が多

図 3 結石部位別の PNL 後 $3 ， 6 ， 12$ カ月に抢ける DMSA 腎摄取率の平均値

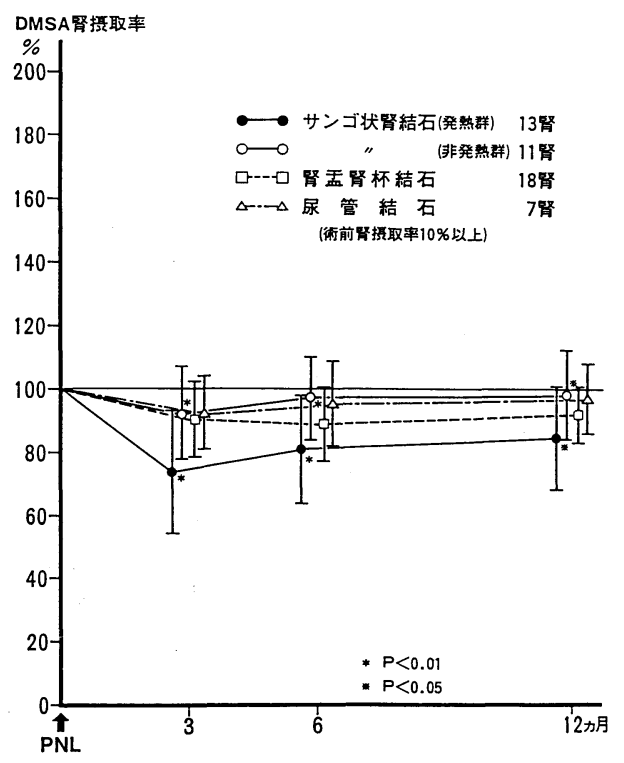

く, 3 カ月後で術前値の $60 \%$ 以下が 13 腎中 4 腎， $80 \%$ 以下が 8 腎もあり， 6 力月後でも $60 \%$ 以下が 3 腎, $80 \%$ 以下が 5 腎認められた（図 2 ）。

PNL 後 $3 ， 6 ， 12$ 力月の DMSA 腎摄取率の変化率 の結石部位別平均值をみると(図 3 ), 術後発熱を合併 しなかったサンゴ状腎結石11腎（術前腎摂取率 $10 \%$ 以 上)では，PNL後 3，6，12力月の值は，それぞれ術 前值の $93.7 ， 98.7 ， 98.3 \%$ と良好なのに対し，術後発 熱を合併したサンゴ状腎結石13腎では, それぞれ74.1， $81.0 ， 84.4 \%$ と有意に低下していた（ $\mathrm{p}<0.05 ）$.

一方，腎盎腎杯結石18腎では，それぞれ術前值の $90.7 ， 88.9 ， 92.1 \%$ ，また尿管結石 7 腎ではそれぞれ 92.6，95.3，97.3\%と，いずれも良好な経過であった。

4. 術前の腎機能によるグループ分類とDMSA 腎 摄取率の長期経過観察

結石の部位に関わらず，術前の IVP 上の水腎の程 度, および腎シンチグラフィー上の腎実質障害の程度 により, 川村の分類 ${ }^{11)}$ 参考に, 全症例をグループ A, B， C，Dの 4 つのグループに分類した（表 3 ）.

グループ A は, IVP 上水腎も正常か軽度で, 腎実質 障害も正常か局所的な腎摄取率の低下にとどまってい る症例で，尿路の閉塞も軽く，感染もなく，腎機能が ほとんど正常に保たれている腎杯結石や，比較的早期 の結石に多い，術前の平均 DMSA 腎摂取率も $22.7 \%$ と正常で, PNL 後の腎摂取率の経過は，ほとんどの症 例が経過良好であった（図 4 ）。

グループ B は，腎実質障害は正常ないし軽度である が，中等度ないし高度の水腎症例で，尿路の閉塞を来 たしているが，腎機能がまだ保たれている比較的早期 の症例に多い. 術前平均 DMSA 堅摄取率は, $21.1 \%$ と ほぼ正常であったが, PNL後の腎摂取率の経過は, 術 後感染を合併した 3 腎のらち 2 腎で PNL 後 3 カ月の

表 3 術前の水腎の程度および腎実質障害の程度によるグループ分類

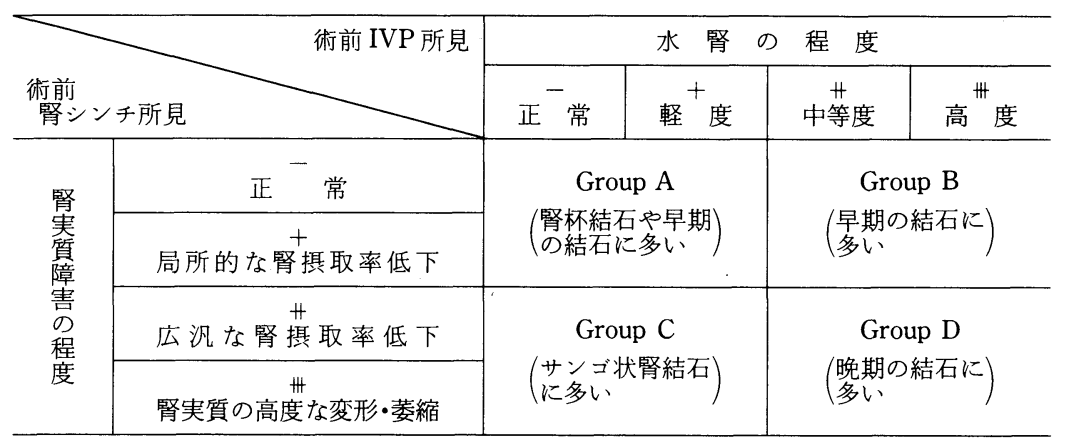


図 4 グループA：腎機能正常(水腎正常ないし軽度) 群17腎に扣ける PNL 後の DMSA 腎摂取率の変動

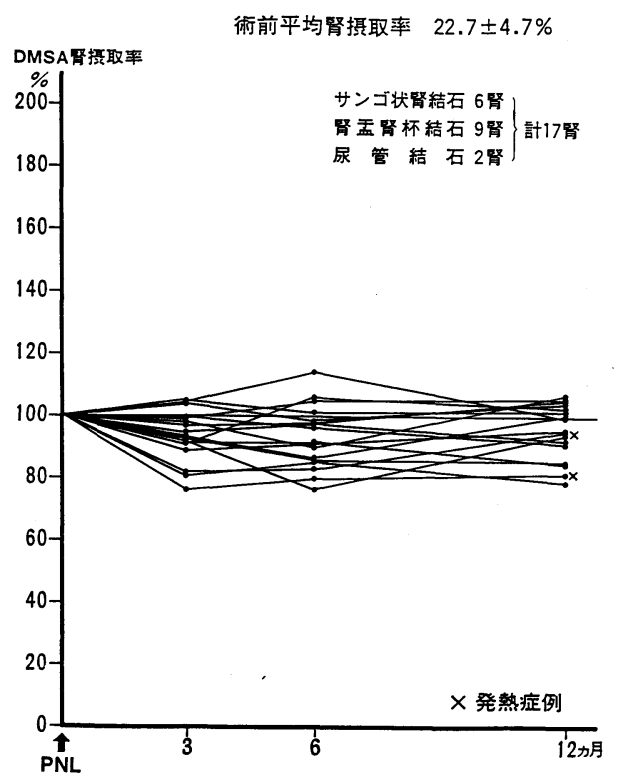

図 5 グループB：腎機能正常（水腎中等度ないし高 度)群12腎に扣ける PNL 後の DMSA 腎拄取率の変 動

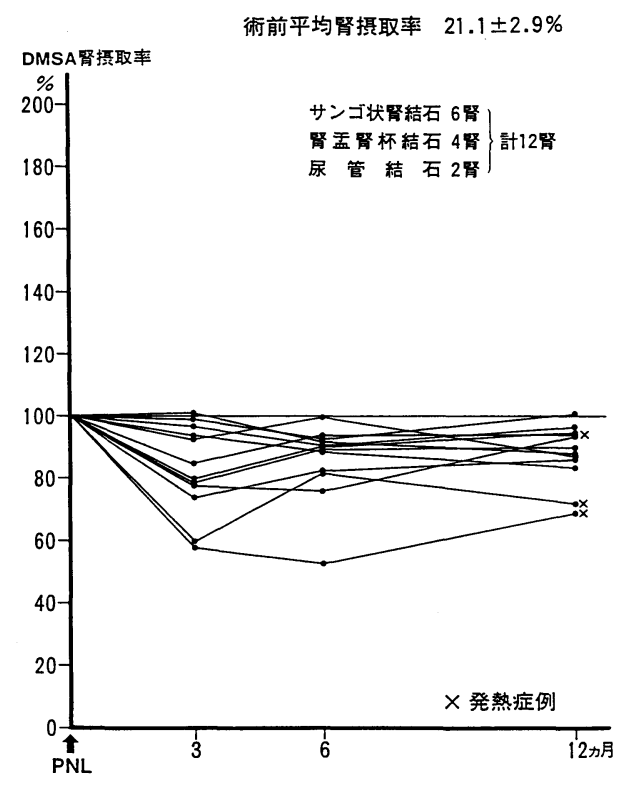

腎撷取率が術前値の約 $60 \%$ と大きく低下しており，ま た他の症例もグループ A に比べて, PNL後の腎摂取 率の回復が不良であった（図 5 ).

グループCは, 正常ないし軽度の水腎症例である
図 6 グループC：腎機能障害(水腎正常ないし軽度) 群 8 腎に扣ける PNL 後の DMSA 腎撖取率の変動

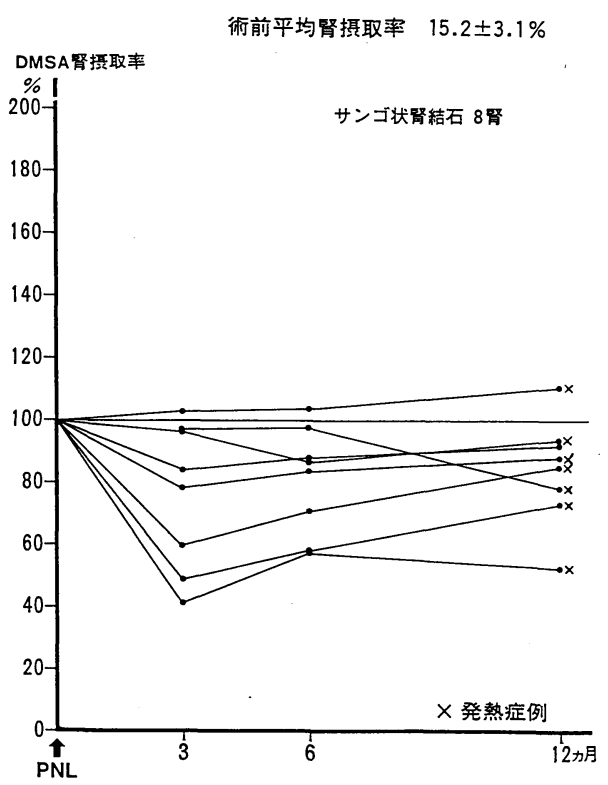

が，腎実質障害が中等度以上の症例で， 8 腎全例がサ ンゴ状腎結石であった。術前平均 DMSA 腎摄取率も， $15.2 \%$ と中程度低下していた. PNL 後の腎摄取率の経 過は, 8 腎中 7 腎で術後感染を合併し，腎摂取率も PNL 後 3 カ月で 8 腎中 4 腎, 12 カ月後で 8 腎中 3 腎が 術前値の $80 \%$ 以下と低下する症例を多く認めた（図 6 ).

グループ D は, 中等度ないし高度の水腎で, 腎実質 障害も中等度以上の症例で, 尿路閉塞を伴いかなり腎 機能の低下した症例である。術前平均 DMSA 腎摂取 率は, $12.2 \%$ とかり低下しており，術前腎摂取率10\% 以下の症例を 4 例含む. PNL 後の腎摂取率の変動は著 しく，上昇するものと低下するものがみられた。 しか し，12カ月後には 13 腎中 12 腎が術前値の $80 \%$ 以上， ち 6 腎が $100 \%$ 以上に回復してお枋，腎摂取率の経過は 良好であった（図 7 ).

つぎに, PNL 後の DMSA 腎摂取率の経過を, Type I (上昇型), Type II (不変型), Type III (回復型), Type IV (低下横ばい型), Type V (低下型) に分類 し,ささら Type I, II を経過良好群, Type III を中間 群, Type IV,Vを経過不良群とした（図 8).

術前の腎機能グループ別に，この術後経過を検討す ると, グループ A は, 術前平均腎摂取率も $22.7 \%$ と良 好で, 術後経過も，17腎中16腎（94.1\%）が経過良好 
図 7 グループ D：腎機能障害（水腎中等度ないし高

度)群13腎に扣ける PNL 後 DMSA 腎摂取率の変動 衍前平均腎摄取率 $12.2 \pm 6.1 \%$

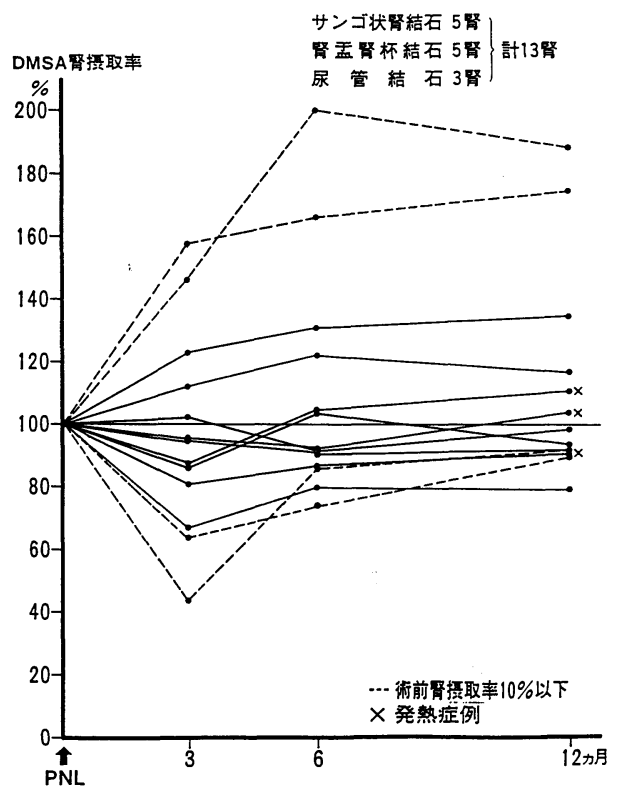

図 8 PNL後の DMSA 腎摂取率の経過によるタイ プ分類

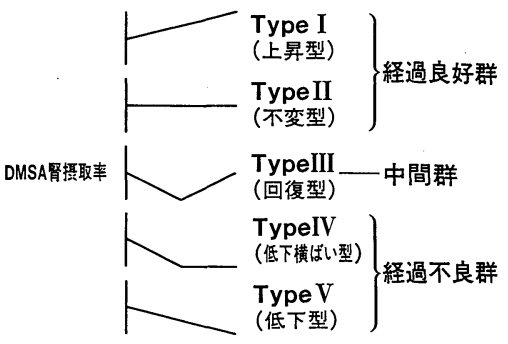

群， 1 腎(5.9\%)が中間群であった。グループ B では, 術前平均摂取率は $21.1 \%$ と良好であったが，術後経過 は12腎中 8 腎 $(66.7 \%)$ が経過良好群， 3 腎（25\%） が中間群， 1 腎 $(8.3 \%)$ が経過不良群であった。グルー プ C では, 術前平均腎摂取率は $15.2 \%$ と中等度低下し て扣り，術後経過は 8 腎中 4 腎 $(50 \%)$ が経過良好群， 2 腎（25\%）が中間群， 2 腎（25\%）が経過不良群で あった。グループ D では，術前平均腎摂取率は $12.2 \%$ と著明に低下していたが，術後経過は13腎中10腎 (76.9\%)が経過良好群， 3 腎(23.1\%)が中間群であっ た（図 9 ).

経過不良群 3 腎（6\%）について，その内訳をみる
図 9 術前グループ別にみた術後経過

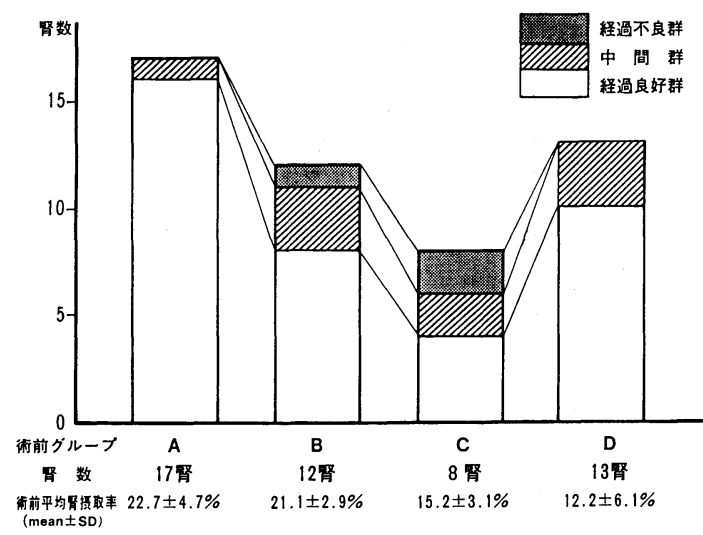

と，3 腎ともサンゴ状腎結石で, 術前の平均 DMSA 腎 摄取率は $14.6 \%$ と中等度低下していた。しかも 3 腎と も，術後発熱を合併した Magnesium ammonium phosphate (以下 MAP) 結石であった。 また，次に述 ベる cold area 残存を 3 腎中 2 腎（66.7\%）に認めた。

次に中間群 9 腎（18\%）について，その内訳をみる と, サンゴ状腎結石が 5 腎, 腎監腎杯結石が 4 腎で, 術前の平均 DMSA 腎撕取率は, グループ D の 2 腎(術 前 DMSA 腎摄取率 $3 \%$ と $9.9 \%$ ）を除くと， $21.3 \%$ と 良好であった。また，cold area 残存は，9腎中 2 腎 （22.2\%）とむしろ少なかった.

\section{Cold area 残存症例の検討}

PNL 前後の腎シンチグラフィーのイメージ像を, 正 面及び側面像でよく観察すると, 腎瘻㨂入部に一致し た low uptake area あるいは cold area が長期間残存 する症例が認められた（図10）。

私達の検討では，50腎中21腎 (42\%) に cold area の 残存を認めた（図11). サンゴ状腎結石（25腎中12腎, 48\%）でやや残存率が高い傾向がみられたが，結石部 位別では，特に有意差は認められなかった。術前腎機 能グループ別では，グループ C ( 8 腎中 5 腎， 62.5\%) 扣よびグループ B (11腎中 6 腎，54.5\%) でやや高く， グループ D（14腎中 3 腎，21.4\%）で低いが，特に有 意差は認められなかった。術後発熱合併群（15腎中 8 腎, $53.3 \%$ ）では, 術後非発熱合併群（35腎中13腎, $37.1 \%$ ）に比べ，有意に cold area の残存率が高かっ た $(\mathrm{p}<0.05)$.

\section{考 察}

1. PNL 後の分腎機能の長期経過について PNL 後の分腎機能の経過を予測する上で, 術前の尿 
図10 40y. 令左腎孟結石症例の PNL 後腎シンチグラム (上段正面像, 下段側面像)：

白矢印の腎瘻插入部に cold area の残存を認める。

Pre PNL

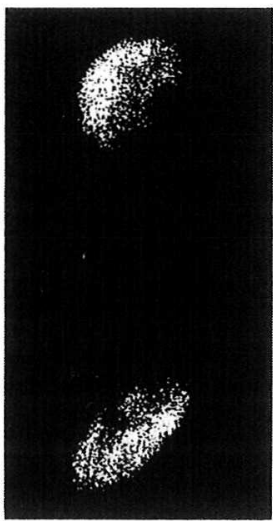

$29.0 \%$
Post PNL

3months

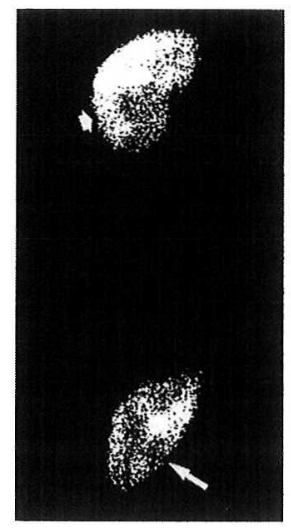

$26.8 \%$
6 months

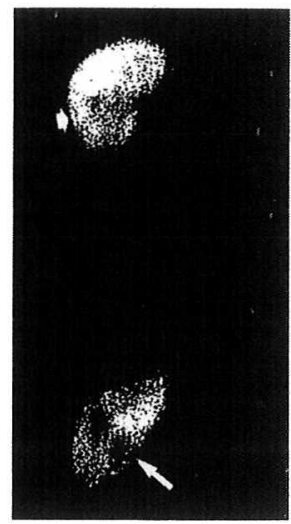

$24.8 \%$
12 months

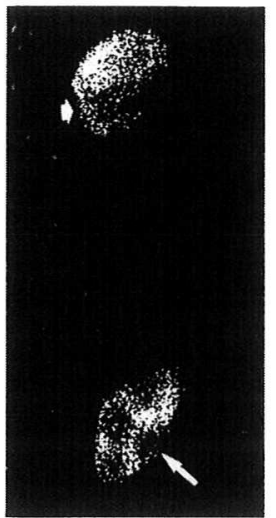

$24.6 \%$

図11 結石部位別, 術前グループ, 発熱合併の有無による PNL 後 cold area の残存率

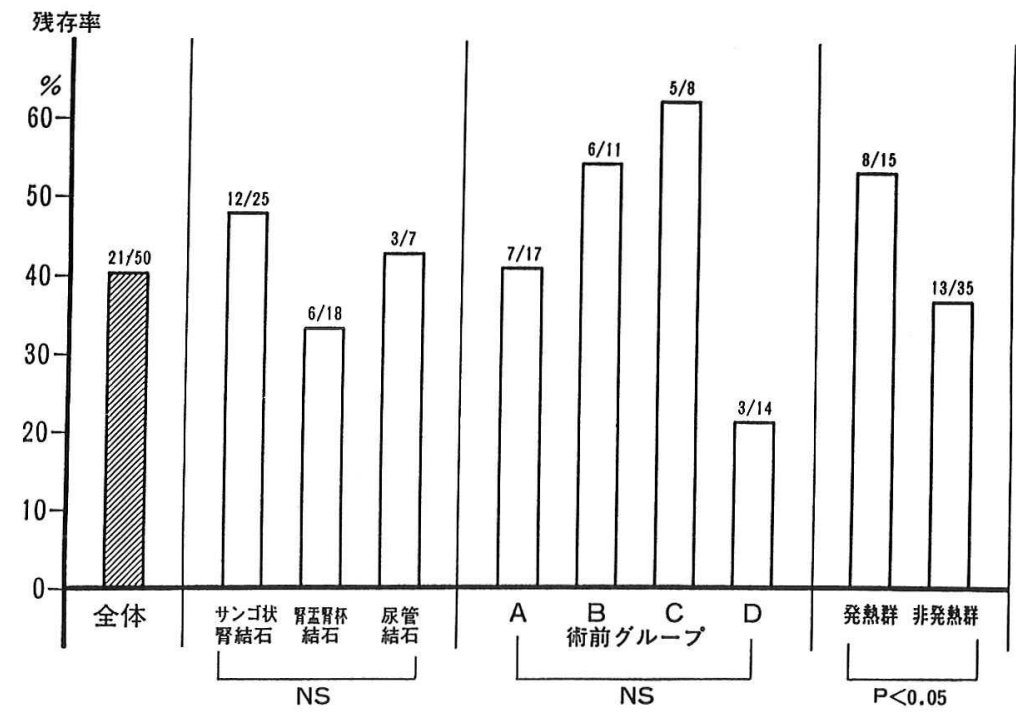

路閉塞の状態と腎機能障害の程度を把握しておく事に は大きな意味があると考兄られる。そこで今回，術前 のIVP と腎シンチグラフィーの所見より, 全症例を結 石の部位に関係なく 4 つのグループに分け，術後の分 腎機能の経過を DMSA 腎摂取率の変化より検討して みた。すなわち、グループ A は結石があっても，尿路 閉塞や感染などによる腎機能への影響をまだ葟とんど 来たしていない状態で PNL 後の腎機能も安定してい
る。たと艺ンゴ状腎結石のような結石であっても， グループ A に含まれるものであれば，PNL後の腎機 能は極めて良好である。従来サンゴ状腎結石に対して 行われていた腎切石術では，腎阻血や腎実質の切開縫 合によって術後かなりの腎機能障害を来たしてお $\eta^{12113)}$ ，それに比べると PNLは極めて画期的な治療 法と言克る ${ }^{14) 15)}$ 。グループ B は，尿路閉塞はきたして いるが腎機能はまだ良好な状態で, 術後の発熱を合併 
した 2 腎を除いて術後経過は良好である。しかし，グ ループ A に比べると PNL 後の腎摂取率の低下は大 きく，また 12 力後の腎摂取率も， ほとんどの症例で PNL 前の腎摂取率より低下している。この原因は, 恐 らく水腎のある状態での腎摂取率が，真の腎皮質機能 より over estimateされているためではないかと考光 られる ${ }^{11)}$ 。グループ C は, 尿路閉塞はほとんど無いの に腎機能障害を来たしている状態で，その原因は，主 に感染による腎孟腎炎を繰返し，腎実質の瘦痕化が進 んだためと考えられる。実際，このグループに含まれ る8腎はすべてサンゴ状腎結石であり，しかも，結石 成分は全例 MAP 単独あるいは混合結石である（サン ゴ状腎結石全体では $81.8 \%$ が，MAP 単独あるいは混 合結石)。このグループ C 打よびグループ B で術後経 過が不良である 2 腎をみても, PNLに際して術後の感 染の合併が PNL 後の腎機能に大きな影響を与える事 が示唆される。

今回 PNLに際して, 術後発熱を合併したサンゴ状 腎結石13腎のうち，1腎を除いて全例が術前の検尿で 膿尿あるいは細菌尿を呈していた。をた，腎結石がか なりの割合で細菌を核にして発育していることはよく 知られた事実 ${ }^{16)}$ であり, 結石の破砕により細菌が尿中 に放出される可能性は大きい. 竹内ら ${ }^{17}$ (100例の PNL 症例に打いて, 感染群では $87 \%$, 非感染群で $36 \%$ に, $38^{\circ} \mathrm{C}$ 以上の発熱の合併がみられたと報告している.

したがって，今後術前すでに尿路感染を合併してい たり，術前のIVP や腎シンチグラフィーの所見より， 特に感染結石が疑われる症例をPNLによって治療す る場合，術前から術後にわたり十分な化学療法をする などの注意により，感染の合併・再発を未然に防ぐこ とが, 腎機能を保つために重要と考えられる ${ }^{18) 19}$. しか し，感染結石の，全身的な抗生剂の投与だけでは，尿 を完全に無菌化することは困難なことが多く，実際竹 内ら ${ }^{17)}$ は，術前 2 日前より抗生剤を投与した群と投与 しなかった群との間で術後の発熱の合併に差がみられ なかったと報告している。したがって，術前尿路感染 を十分に抑兄きれない場合には，まず細い腎瘦を挿入 し。抗生剂を含む潅流液により。十分腎孟内潅流を抹 こなったのち， 2 期的に PNLを施行する方がよいと 思われる。

グループ D は，尿路閉塞と腎機能障害を来たしてい る状態で, PNL 前の腎摂取率もかなり低下している症 例が多く, PNL 後の腎摂取率の変動は大きく低下する ものと上昇するものがみられる。このグループ Dでは
尿路閉塞が腎摂取率の低下の大きな原因となって抒 り，PNLにより尿路閉塞を解除することにより PNL 後の腎摂取率が回復する症例が多いと思われる。

2。PNLによる局所的腎実質障害について

PNL でも, $24 \mathrm{Fr}$ 程度の腎瘦を作製するため, 腎実質 の局所挫滅は避けられず，また腎血管に対する損傷が 当然問題となる ${ }^{20211}$ 。乙いか, 腎血管に対しては, 我々 が開発した $22 \mathrm{G}$ の穿刺針を超音波ガイド下に確実に腎 杯に穿刺し，そのルートを徐々に拡張していく腎瘦造 設法 ${ }^{22)}$ により, 解剖学的に葉間動静脈以上の比較的太 い腎血管に対する損傷の危険はないと考兄られ

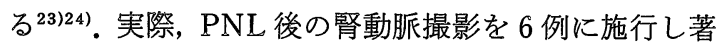
変を認めなかったとの松岡ら ${ }^{25)}$ の報告もある。しかし 一方，Ekelund ら ${ }^{26)}$ は，超音波を用いず，2 方向から のX-ray 透視下に造設した，30ないし33Fr の腎瘦か ら行った PNLで, 術後 6 日目の腎動脈造影にて, 腎瘦 に一致して楔形の欠損所見を10例中 5 例に認めてい る.

私達の検討では, PNL 後の腎シンチグラムを, 正面 像のみでなく側面像でもよく観察すると，実に $40 \%$ も の症例で腎瘦插入部に cold area の長期残存を認め た。この cold area 残存の原因は，腎㾞による局所的 腎実質障害と考えられる。その障害の程度について， 3 分割腎シンチグラフィーとダイナミック CT を施行 し検討中であるので，次回に報告する予定である。

\section{結 語}

経皮的腎尿管結石摘出術（PNL）の，腎機能への影 響について, ${ }^{99 m} \mathrm{~T}$ c-DMSA 腎シンチブラフィーを用い て，長期経過観察を扣こなった。

DMSA 腎摂取率により, PNL 後 1 年間の分腎機能 の変化を観察すると，50腎中38腎（76\%）が経過良好 群。18腎（18\%）が中間群， 3 腎（6\%）が経過不良 群であった。

経過不良群の 3 腎はすすべて術後発熱を合併したサ ンゴ状腎結石であり，実際。術後発熱を合併したサン ゴ状腎結石13腎の PNL 後の平均 DMSA 腎摂取率は, 術後発熱を合併しなかったサンゴ状腎結石 12 腎の平均 DMSA 腎摂取率を比較して，有意に低下していた。

今後, PNLを更に腎機能への影響の少ない方法とし て確立していくためには，特に感染を合併しやすいサ ンゴ状腎結石では十分な化学療法などにより，感染を 予防するとともに，さらに腎実質への局所障害につい ての，検討が急務と考光られた。

稿を終えるにあたり，御指導いただきました桑原正明助 
教授および棚橋善克講師に心から感謝致します.また, 御援 助, 御協力をいただいた仙台社会保険病院放射線科中道五 郎先生ならびに各位に厚く招礼申し上げます。

なお，本論文の一部は，第54回日本泌尿器科学会東部総 会, 第75回日本泌尿器科学会総会, 第52回日本超音波医学会 で発表した。

\section{文献}

1) Fernström, I. and Johansson, B.: Percutaneous pyelolithotomy: A new extraction technique. Scand. J. Urol. Nephrol., 10, 257-259, 1976.

2) Alken, P., Hutschenreiter, G., Günther, R. and Marberger, M. : Percutaneous stone maipulation. J. Urol., 125, 463-466, 1981.

3) White, E.C. and Smith, A.D.: Percutaneous stone extraction from 200 patients. J. Urol., 132, 437-438, 1984.

4) Lee, W.J., Smith, A.D., Cubelli, V. and Vernace, F.M.: Percutaneous nephrolithotomy: Analysis of 500 consecutive cases. Urol. Radiol., 8, 61-66, 1986.

5) Segura, J.W., Patterson, D.E., Leroy, A.J., Williams, H.J. Jr., Barrett, D.M., Benson, R.C. Jr.,May, G.R. and Bender, C.E. : Percutaneous removal of kidney stiones: Review of 1000 cases. J. Urol., 134, 1077-1081, 1985.

6) 千葉 裕, 棚橋善克, 桑原正明, 原田一哉, 豊田精 一, 沼田 功, 前原郁夫, 折笠精一: 経皮的腎尿管 結石摘出術，日泌尿会誌，74，1758-1764，1983.

7) 棚橋善克, 千葉 裕, 桑原正明, 沼田 功, 豊田精 一, 黒須清一, 前原郁夫, 田口勝行, 折笠精一: 経 皮的腎尿管結石摘出術(第 2 報). 日泌尿会誌, 76, 1314-1322, 1985.

8) Kawamura, J., Hosokawa, S. and Yoshida, O.: Renal function studies using ${ }^{99 \mathrm{~m}} \mathrm{Tc}$ dimercaptosuccinic acid. Clin. Nucl. Med., 4, 39-46, 1979.

9）折笠精一：腎瘦造設法.「経皮的腎・尿管結石摘出 術」. p. 29-43, 金原出版, 東京, 1986 .

10）川村寿一： ${ }^{99 m} \mathrm{Tc}$-DNSA 腎シンチグラフィー「腎 シンチグラフィー」一腎の機能と形態検査一. p. 19-50, 南江堂, 東京, 1981 .

11）川村寿一：画像診断による水堅症の機能評価. 臨 泌，40, 267-275, 1986.

12) Thomas, R., Lewis, R.W. and Roberts, J.A.: The renal quantitative scintillation camera study for determination of renal function after anatrophic nephrolithotomy. J. Urol., 125, 287-288, 1981.

13) Kawamura, J., Itoh, H., Okadam, Y., Higashi, Y., Yoshida, O., Fujita, T. and Torizuka, K. Preoperative and postoperative cortical func- tion of the kidney with staghorn calculi assessed by ${ }^{99 m}$ Technetium-dimercaptosuccinic acid renal scintigraphy. J. Urol., 130, 430-433, 1983.

14) Snyder, J.A. and Smith, A.D.: Staghorn calculi : Percutaneous extraction versus anatrophic nephrolithotomy. J. Urol., 136, 351-354, 1986.

15）東原英二, 岸 洋一, 梅田 隆, 岩動孝一郎, 新島 端夫：腎鋳型結石の新しい治療法-ESWL, PNL, 化学溶解の併用療法一. 日泌尿会誌, 77, 1416-1420, 1986.

16) Griffith, D.P.: Structive stiones. kidney International, 13, 372-382, 1978.

17）竹内秀雄, 上田 真, 野々村光生, 飛田收一, 大島 賢二, 東 義人, 岡田裕作, 川村寿一, 吉田 修: 経皮的腎碎石術（PNL）および経尿道的尿管砕石 術（TUL）にみられる発熱について。泌尿紀要, 33, 1357-1363, 1987.

18）清田 浩, 町田豊平, 田代和也, 鈴木正泰, 秋田鉄 郎, 後藤博一：経皮的腎尿管切石術後の尿路感染 症. 臨泌, 40, 475-478, 1986.

19) Fowler, J.E. Jr.: Bacteriology of branch ed renal calculi an, accompanying urinary tract infection. J. Urol., 131, 213-215, 1984.

20) Harris, R.D. and Walther, P.C. : Renal arterial injury associated with percutaneous nephrostomy. Urol., 23, 215-217, 1984.

21) Clayman, R.V., Surya, V., Hunter, D., Castaneda-Zuniga, W.R., Miller, R.P., Coleman, C., Amplatz, K. and Lange, P.H. : Renal vascular complications associated with the percutaneous removal of renal calculi. J. Urol., 132, 228-230, 1984.

22）千葉 裕, 棚橋善克, 沼田 功, 豊田精一, 前原郁 夫, 田口勝行 : 超音波穿刺術 (第 3 報)一特に結石 出を目的とした安全な腎瘻術の工夫一。 日超医論 文集，46，839-840，1984.

23) Boyce, W.H., Russell, J.M. and Webbm,: R.: Management of the papillae during intrarenal surgery. Trans. Amer. Ass. Genito Urinary Surg., 71, 76--82, 1979.

24) Kaye, K.W. and Reinke, D.B.: Detailed caliceal anatomy for endourology. J. Urol., 132, 1085-1088, 1984.

25）松岡 啓, 植田省吾, 国見 宏, 村上雅已, 野田進 士，江藤耕作：経皮的腎尿管結石摘術の腎に及ぼ す影響. 第 1 報。腎機能への影響. 日泌尿会誌, 78 , 1337-1344, 1987.

26) Ekelund, L., Lindstedt, E., Lundquist, S.R., Sundid, T. and White, T.: Studies on renal damage from percutaneous nephrolitholapaxy. J. Urol., 135, 682-685, 1986.

（1988年 5 月 25 日受理，特別掲載） 